UDC 629.5.052.3+621.396.67.012.12

\title{
MULTIPLE DIRECTION INTERFERENCE SUPPRESSION BY UNIFORM LINEAR PHASED ARRAY SIDELOBE EFFICIENT CANCELLER
}

\author{
Vadim V. Romanuke \\ Polish Naval Academy, Gdynia, Poland
}

Background. For radar systems, the beam pattern of a uniform linear array (ULA) is synthesized to ensure signal selectivity by direction. A specific ULA sidelobe is cancelled by rescaling the beam weights. In particular, this is done by increasing the number of sensors and shortening the scanning step. However, a noticeable limitation is a loss of the transmitted power. Therefore, the problem is to optimally balance the number of sensors versus effective ULA sidelobe cancellation.

Objective. In order to ensure multiple direction interference suppression, the goal is to find an optimal number of ULA radar sensors for the beam pattern synthesis. The criterion is to determine such a minimum of these sensors at which mainlobes towards useful signal directions are evened as much as possible.

Methods. To achieve the said goal, the ULA sidelobe cancellation is simulated. The simulation is configured and carried out by using MATLAB ${ }^{\circledR}$ R2020b Phased Array System Toolbox ${ }^{\mathrm{TM}}$ functions based on an algorithm of the sidelobe cancellation.

Results. By increasing the number of ULA sensors, the beam pattern lobes are not only thinned but also change in their power. In particular, the interference direction sidelobes become relatively stronger. The number of sensors is limited by the three influencing factors: the thinned-array curse transmitted power loss, the aperture size, and the sidelobes intensification.

Conclusions. An optimal number of ULA radar sensors for the beam pattern synthesis can be found when the scanning step is equal to the least distance between adjacent interference directions. At the start, the number of sensors is set at the number of useful signal directions. If the mainlobes towards useful signal directions are not evened enough, the set of interference directions is corrected.

Keywords: radar phased array; beam pattern; interference direction; sidelobe cancellation; aperture size.

\section{Beam pattern synthesis}

In radio, radar services, and telecommunication systems, to efficiently identify and localize sources of space-time wavefields, phased arrays are used [1], [2]. Using an array of sensors, data are collected over a spatiotemporal aperture and processed. At the receiver, phased array systems implement algorithms to extract temporal and spatial information about the sources of energy. Thus, the performance is significantly improved over a single sensor [1], [3], [4].

For radar systems, the beam pattern of a uniform linear array (ULA) is synthesized to ensure signal selectivity by direction [5], [6]. This is a common task because the area scanned by a radar can have interferers [7], [8]. These interferers and their directions are presumed to be determined. For instance, a mobile radar system may need to suppress interference from nearby radio stations whose locations are known [9], [10].

A proper beam pattern synthesis is done for suppressing the interference. For this, a specific ULA sidelobe is cancelled. The canceller is constructed by rescaling the beam weights [5], [11]. In particular, this is done by increasing the number of sensors and shortening the scanning step. The mainlobes are evened in this way. However, there is a limitation because of the well-known thinned-array curse theorem [12], [13]. Due to the theorem, the amount of power beamed into mainlobe is reduced by an amount proportional to the ratio of the ULA area to the total area of sensor apertures. Thus, there is a loss of the transmitted power, although the interference is then efficiently suppressed [1], [2], [6], [14], [15]. Therefore, the problem is to optimally balance the number of smaller antennas (sensors) versus effective ULA sidelobe cancellation.

\section{Goal formulation}

In order to ensure multiple direction interference suppression, the goal is find an optimal number of ULA radar sensors for the beam pattern synthesis. The criterion is to determine such a minimum of these sensors at which mainlobes towards useful signal directions are evened as much as possible. To achieve the said goal, the ULA sidelobe cancellation is to be simulated by using MATLAB ${ }^{\circledR}$ R2020b Phased Array System Toolbox ${ }^{\mathrm{TM}}$ (PAST) functions. First, the simulation parameters and set-up are to be described. Along with that, an algorithm of the sidelobe cancellation will be stated. Next, the simulation of ULA sidelobe canceller is carried out and appropriate inferences are made from it. The results obtained from the simulation will be discussed with a purpose to 
mention all limitations and controversies. The research will be concluded with factual recommendations of how to improve the beam pattern synthesis by efficiently suppressing multiple direction interference.

\section{Simulation parameters and set-up}

The PAST functions used for simulation are $\psi$ (phased.ULA) and $\theta$. Function $\psi$ creates and models a ULA formed with identical sensor elements. The origin of the local coordinate system is the phase center of the array. The positive abscissa axis is the direction normal to the array, and the elements of the array are located along the ordinate axis. Function $\theta$ returns the steering vector for each incoming set of plane waves impinging on a sensor array. The steering vector represents the set of phase-delays for an incoming wave at each sensor element. The inputs of $\theta$ are the sensor element positions and the incoming wave arrival directions specified by their azimuth and elevation angles. By default, the elevation angles are zero [1], [3], [16], [17].

If $f_{\text {carrier }}$ is a signal carrier frequency, then [18], [19]

$$
\lambda=299792458 / f_{\text {carrier }}
$$

is the wave length. Let $M$ be a number of useful signal directions. The set of these directions in azimuth angles (degrees) is

$$
S=\left\{s_{m}\right\}_{m=1}^{M} .
$$

Let $I$ be a number of interference directions. The set of these directions in azimuth angles (degrees) is

$$
D=\left\{d_{i}\right\}_{i=1}^{I} .
$$

Function $\psi$ creates a ULA radar of $N$ sensors with a distance of $\lambda / 2$ between two adjacent sensors. The sensor positions are [20], [21]

$$
\mathbf{P}=\left\{p_{i}\right\}_{i=1}^{N}=\left\{-\frac{N-1}{2} \cdot \frac{\lambda}{2}+(i-1) \cdot \frac{\lambda}{2}\right\}_{i=1}^{N} .
$$

First, an $(M \cdot N) \times M$ matrix $\mathbf{W}_{S}$ of steering vectors for useful signal directions (2) is found by mapping $\mathbf{P} / \lambda$ and set (2) via function $\theta$ :

$$
\mathbf{W}_{S}=\theta(\mathbf{P} / \lambda, S) .
$$

An $(M \cdot N) \times I$ matrix $\mathbf{W}_{D}$ of steering vectors for interference directions (3) is found similarly by mapping $\mathbf{P} / \lambda$ and set (3) via function $\theta$ :

$$
\mathbf{W}_{D}=\theta(\mathbf{P} / \lambda, D) .
$$

Then the response of desired steering at interference directions (3) is found [5], [11], [12], [22]:

$$
\mathbf{R}_{D}=\left(\mathbf{W}_{D}^{\mathrm{T}} \cdot \mathbf{W}_{S}\right)^{\mathrm{T}} \cdot\left(\mathbf{W}_{D}^{\mathrm{T}} \cdot \mathbf{W}_{D}\right)^{-1},
$$

whereupon the response is cancelled:

$$
\mathbf{W}=\mathbf{W}_{S}-\mathbf{W}_{D} \cdot \mathbf{R}_{D}^{\mathrm{T}} .
$$

For simulation, it is sufficient to set $f_{\text {carrier }}=5 \mathrm{GHz}$. So, number $N$ and sets (2) and (3) are to be varied.

\section{Simulation of ULA sidelobe canceller}

Consider a case when a radar scans between $-45^{\circ}$ and $45^{\circ}$ with a step of $15^{\circ}$, and there are four interferers at $20^{\circ}$ to $35^{\circ}$ spaced $5^{\circ}$ apart. Thus, there are seven useful signal directions. So, let the radar be of seven sensors:

$$
\begin{gathered}
S=\{-45+15 \cdot(m-1)\}_{m=1}^{7}, \\
D=\{20+5 \cdot(i-1)\}_{i=1}^{4}, N=7 .
\end{gathered}
$$

The linear and polar beam patterns for this case are shown in Fig.1. Whereas the sidelobes for the interference directions are cancelled indeed effectively, it is well seen that the mainlobe towards $45^{\circ}$ is too weak. Obviously, this cannot be rectified by decreasing the number of sensors. Increasing the number of sensors to $3 N$ evens the mainlobes, but then the sidelobes are cancelled less effectively (the normalized power increases up to $-20 \mathrm{~dB}$ compared to $-65 \mathrm{~dB}$ seen in the linear beam pattern of Fig.1). This is caused by the radar scanning is too sparse [7], [12], [23], [24].

Therefore, consider the same case in which the scanning is fulfilled with the step equal to the interference direction spacing:

$$
\begin{gathered}
S=\{-45+5 \cdot(m-1)\}_{m=1}^{19}, \\
D=\{20+5 \cdot(i-1)\}_{i=1}^{4}, N=19 .
\end{gathered}
$$

The linear and polar beam patterns for this case are shown in Fig.2. Now, the sidelobes are cancelled less effectively (reaching up to $-22.5 \mathrm{~dB}$ ) compared to Fig.1. The mainlobe at direction $s_{18}=40^{\circ}$ is weaker than at the other useful signal directions. Another option is to use the number of sensors equal to the sum of the number of useful signal directions and the number of interferers:

$$
N=M+I \text {. }
$$

In this case, the mainlobes at directions $s_{18}=40^{\circ}$ and $s_{19}=45^{\circ}$ are almost evened with the remaining 17 mainlobes, but the sidelobes towards interferers are grown up to $-16 \mathrm{~dB}$. This is not an effective sidelobe cancellation. Other simulations distinctly prove that setting $N=M$, in the case when the spacing in (2) and (3) is the same, is quasi-optimal (i. e., it is efficient). 


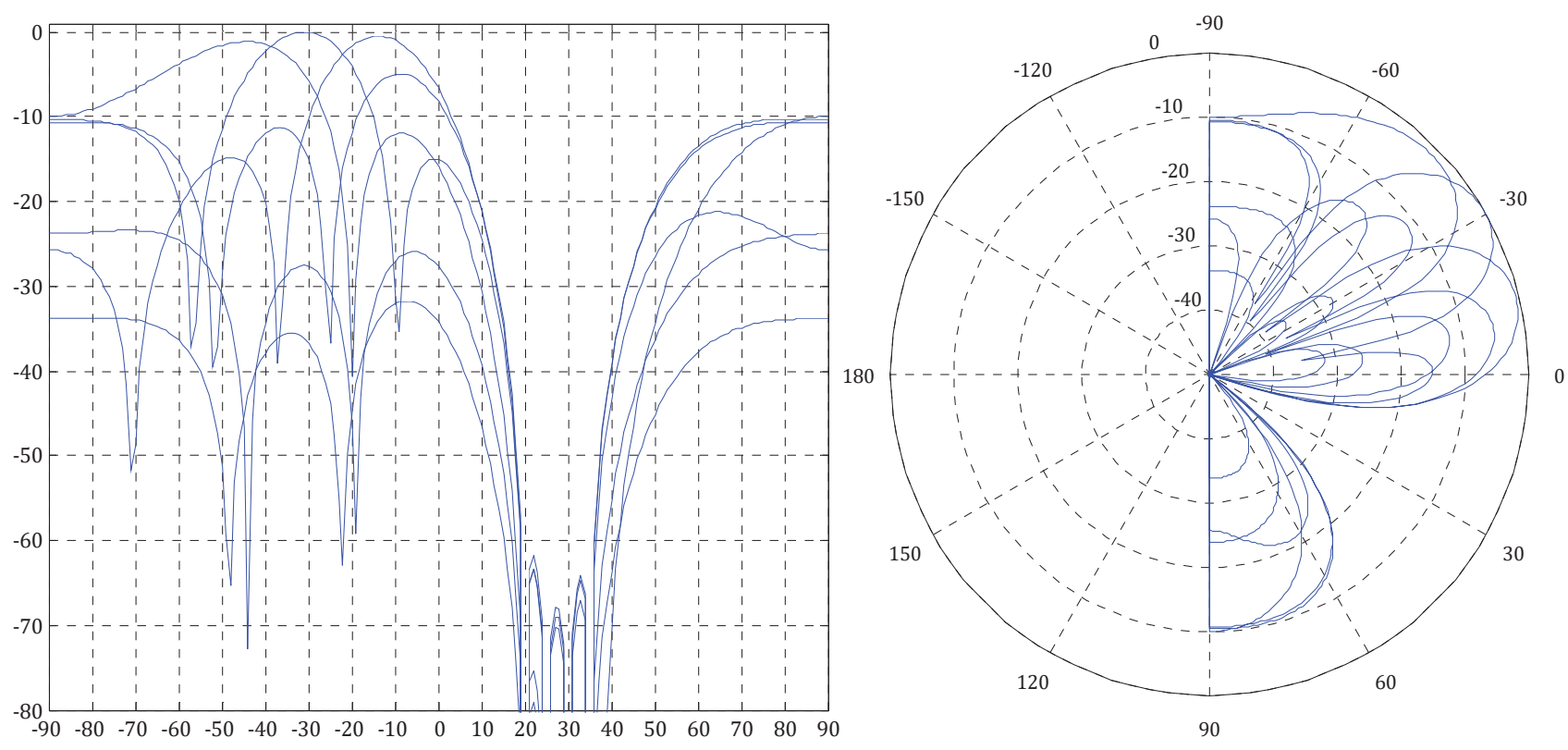

Fig.1. The linear and polar beam patterns (normalized power in $\mathbf{d B}$ ) for case (9)
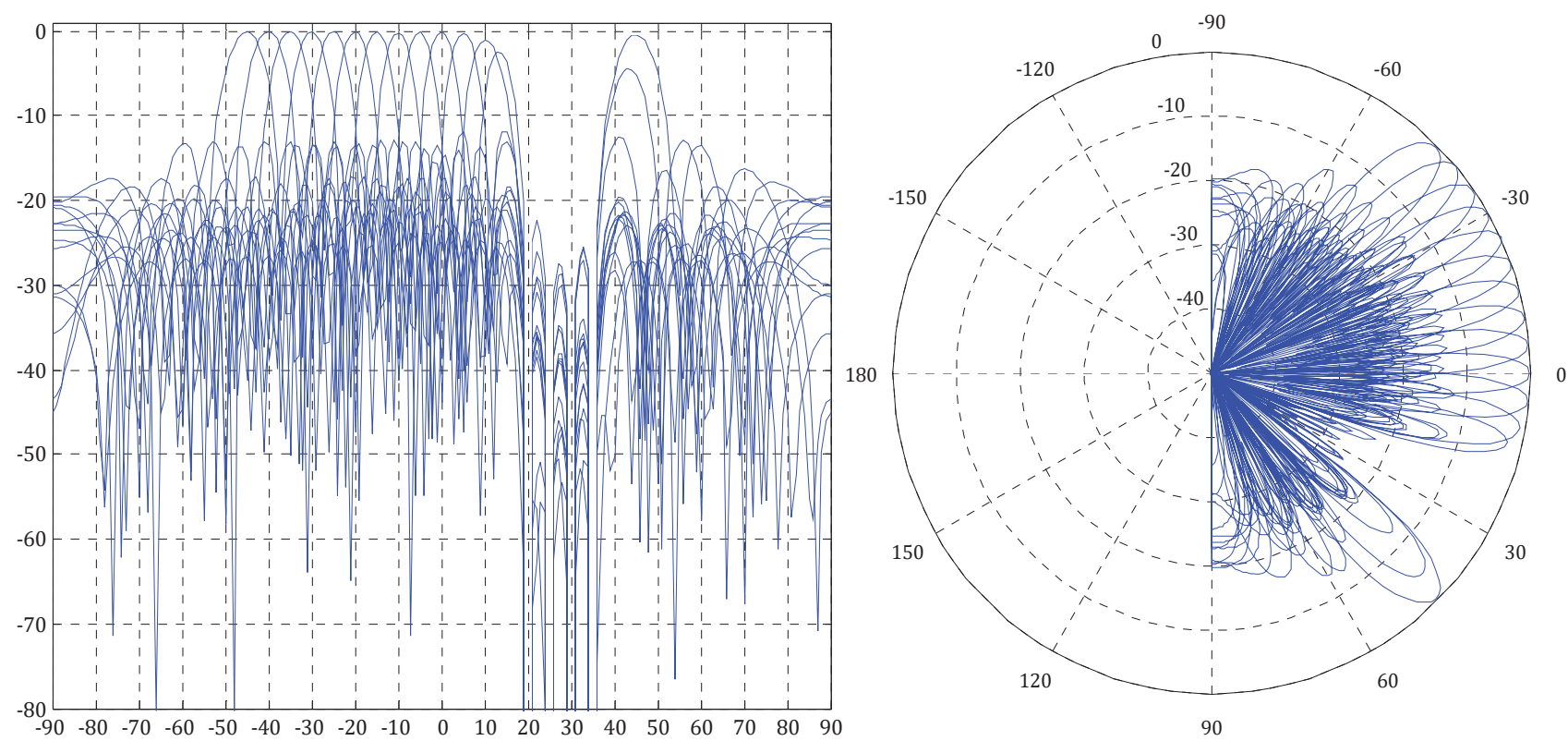

Fig.2. The linear and polar beam patterns (normalized power in $\mathrm{dB}$ ) for case (10)

It is also worth noting that the aperture size is $56.96 \mathrm{~cm}$ in case (10), whereas it is $68.95 \mathrm{~cm}$ by increasing the number of sensors by 4 according to (11). This is another contra against setting the number of sensors as (11).

An important note is that, unlike the interference direction spacing, the radar scanning step is commonly the same. This implies that the elements of set (2) are equidistant [3], [14], [22], [25]. On the contrary, set (3) may be non-equidistant. Moreover, the interference directions are not necessarily enclosed within the margins of the scanning area [26], [27], i. e. inequality

$$
s_{1} \leqslant d_{1}<d_{I} \leqslant s_{M}
$$

does not always hold. For instance, consider a case when

$$
\begin{gathered}
S=\{-60+10 \cdot(m-1)\}_{m=1}^{13}, N=13, \\
D=\{-45,-35,-10,-5,15,40,55,65,70\} .
\end{gathered}
$$

The beam pattern for case (13) shown in Fig.3 is not effective as a sidelobe canceller because the mainlobe at $s_{13}=60^{\circ}$ is too weak. If to exclude $d_{8}=65^{\circ}$ and 
$d_{9}=70^{\circ}$ from set $D$ due to they are not in the range of set $S$, the interference cancellation worsens further. If the scanning step is possible to shorten, it should be made equal to the least distance between adjacent interference directions in set $D$. Thus, in case (13) it corresponds to a case when

$$
\begin{aligned}
& S=\{-60+5 \cdot(m-1)\}_{m=1}^{25}, N=25, \\
D= & \{-45,-35,-10,-5,15,40,55,65,70\} .
\end{aligned}
$$

The beam pattern for case (14) shown in Fig. 4 is more effective as a sidelobe canceller because the mainlobe at $s_{13}=60^{\circ}$ now is stronger $(-15.5 \mathrm{~dB}$ versus $-35 \mathrm{~dB}$ in Fig.3). Then, surely, there is a loss in the ULA geometry as the aperture size is $74.95 \mathrm{~cm}$ which is almost twice as longer as in case (13). If it is impossible to shorten the scanning step, then the only way is to increase the number of sensors. If $N=2 M$ then, compared to Fig.3, the mainlobes at $s_{12}=50^{\circ}$ and $s_{13}=60^{\circ}$ are strengthened up to $-3.24 \mathrm{~dB}$ and $-14 \mathrm{~dB}$, respectively. The aperture size, however, becomes $77.95 \mathrm{~cm}$, which may be crucial in geometrical terms. To adjust it, a few sensors can be removed [28], [29].
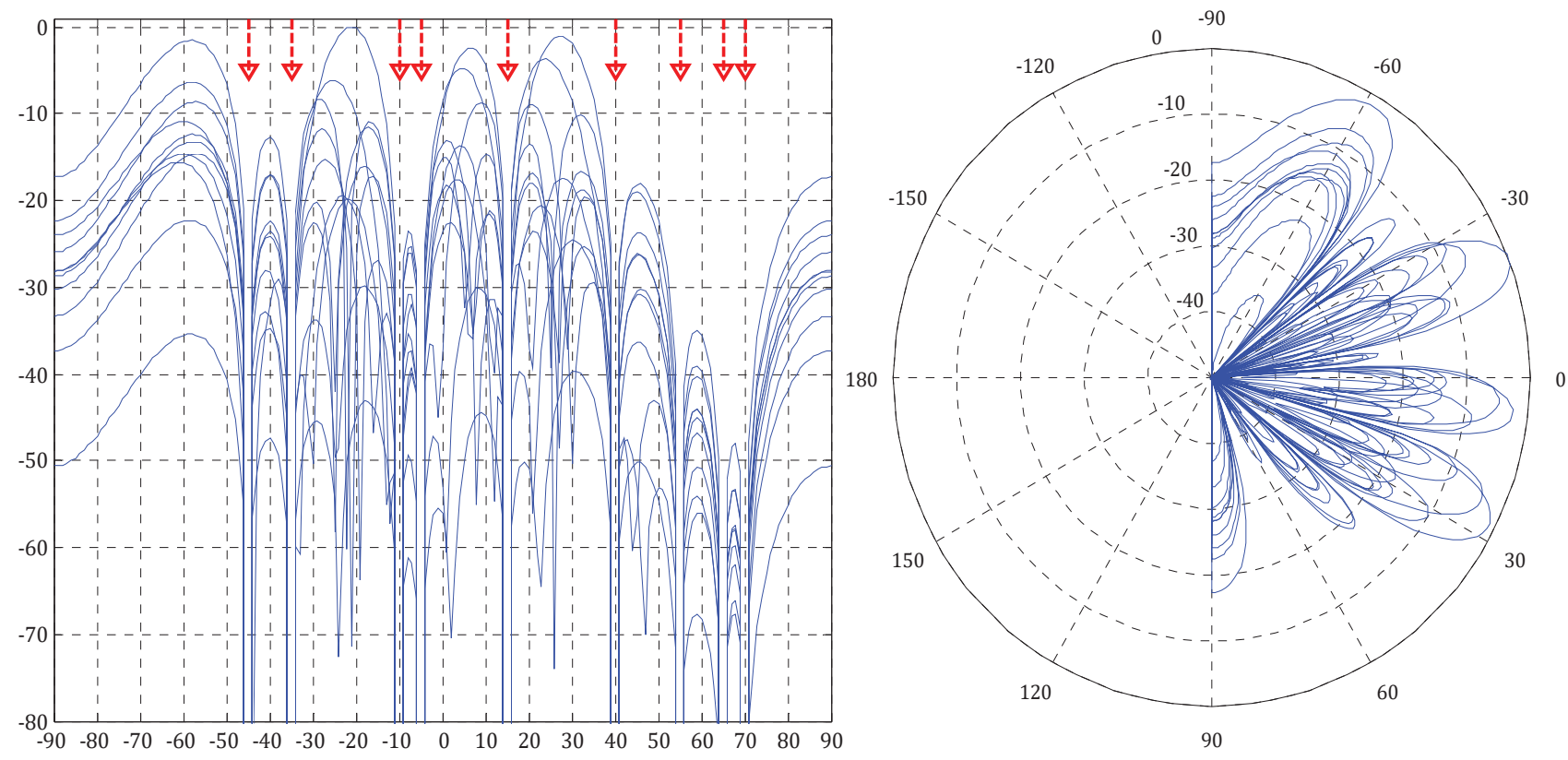

Fig.3. The linear and polar beam patterns (normalized power in $\mathrm{dB}$ ) for case (13) with interference pointers
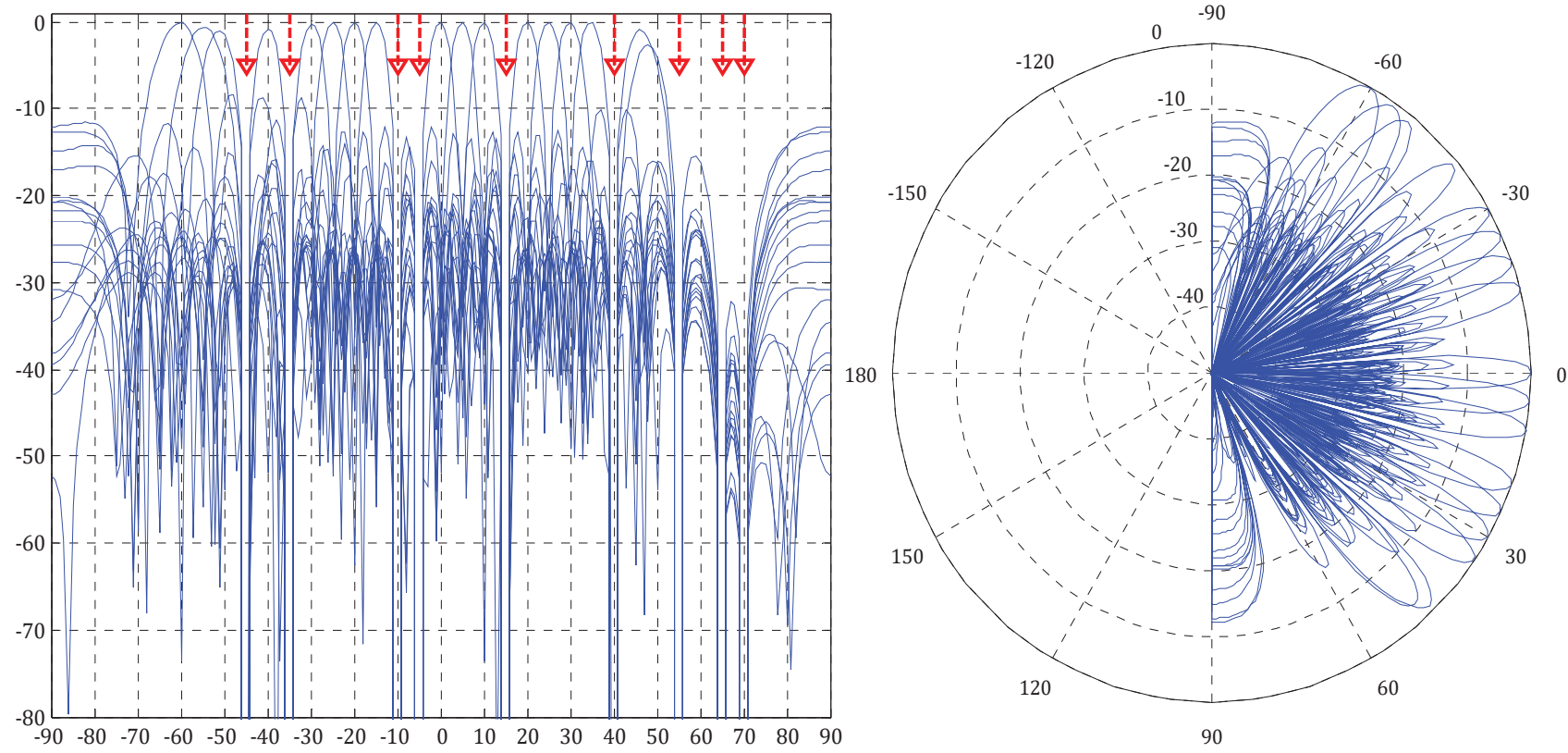

Fig.4. The linear and polar beam patterns (normalized power in $\mathrm{dB}$ ) for case (14) with interference pointers 
Consider a more complicated case, in which there are 10 interference directions and two of them are beyond the range of the radar scanning:

$$
\begin{gathered}
S=\{-80+5 \cdot(m-1)\}_{m=1}^{21}, N=21, \\
D=\{-35,-33,-30,-16,-13,-9,8,12,24,28\} .
\end{gathered}
$$

Thus, the radar scans between $-80^{\circ}$ and $20^{\circ}$ with a step of $5^{\circ}$, but the least distance between adjacent interference directions in set $D$ is less than $5^{\circ}$. The ULA sidelobe canceller must suppress the interference at azimuth angles $8^{\circ}$ and $12^{\circ}$ by maintaining a strong mainlobe at $s_{19}=10^{\circ}$. Fig. 5 shows that the respective beam pattern is not applicable. First, the direction at $-85^{\circ}$ is not a useful signal direction, but its power is almost maximal. Second, the mainlobe at $s_{19}=10^{\circ}$ is too weak. So, set $D$ is corrected as follows:

$$
\begin{gathered}
S=\{-80+5 \cdot(m-1)\}_{m=1}^{21}, N=21, D=\{-90, \\
-35,-33,-30,-16,-13,-9,7,13,24,28\} .
\end{gathered}
$$

Fig.6 shows that, owing to the corrections in set $D$, these two demerits are almost rectified [30], [31].
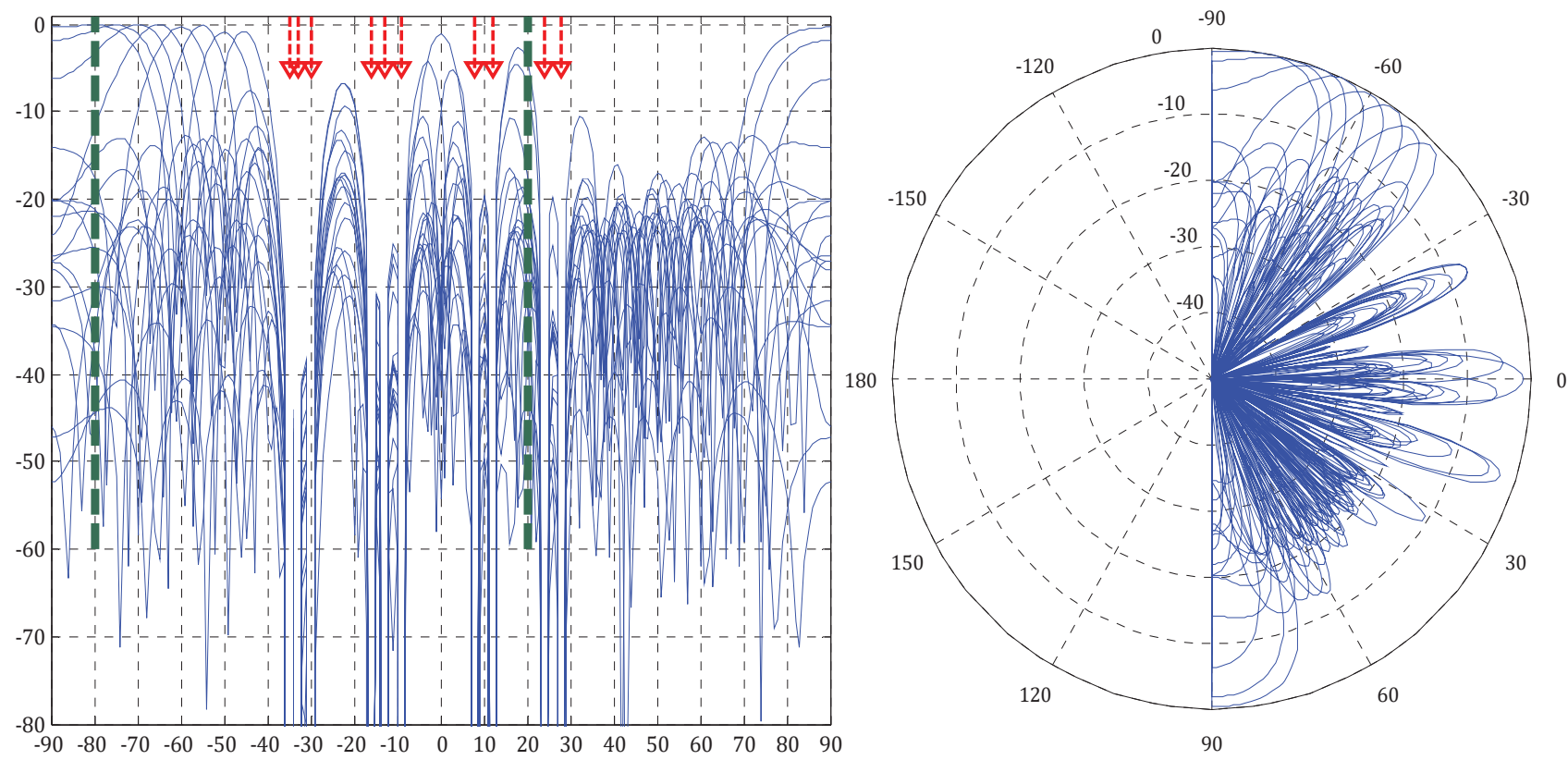

Fig.5. The linear and polar beam patterns (normalized power in $\mathrm{dB}$ ) for case (15) with the radar range margins
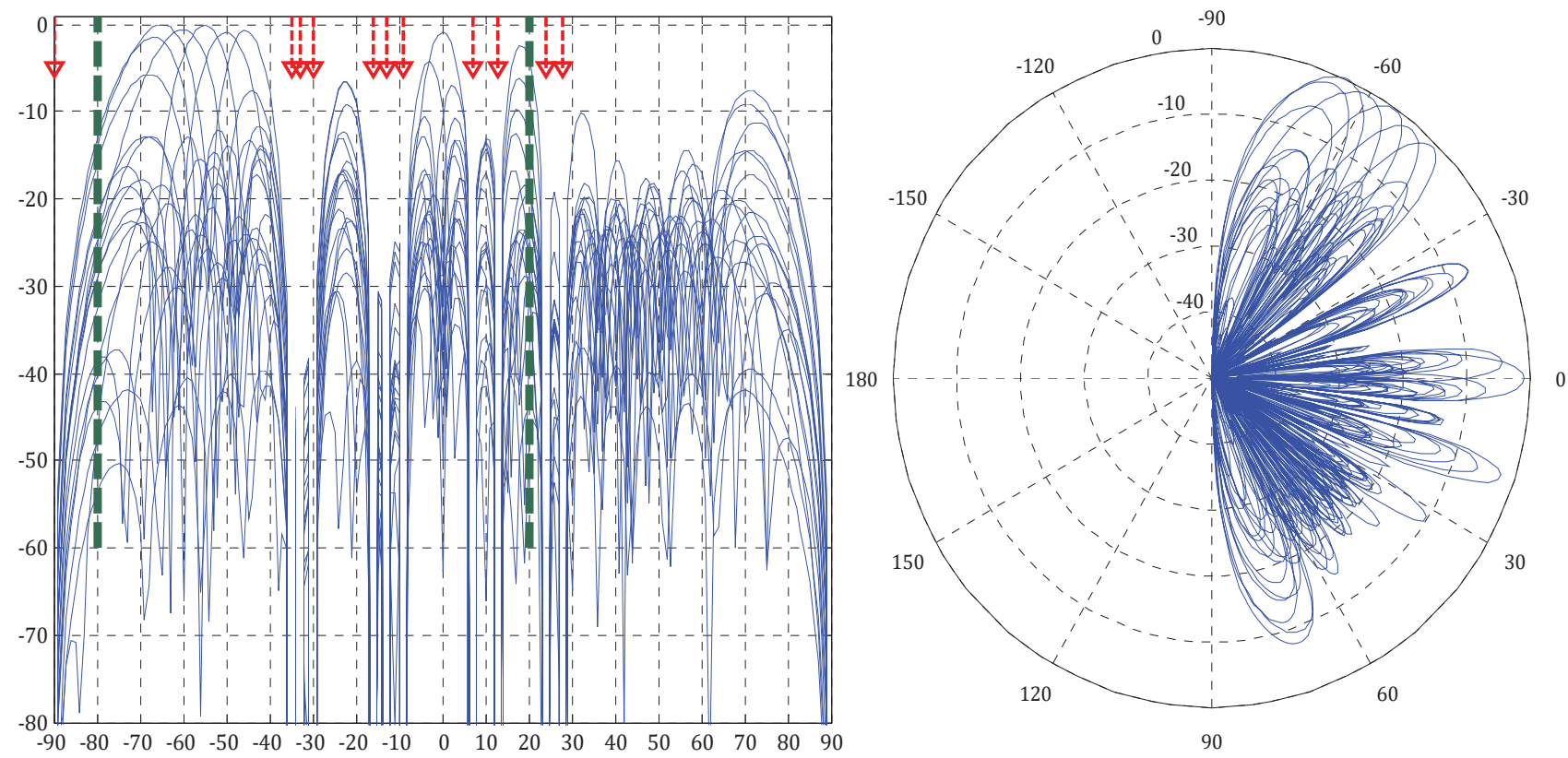

Fig.6. The linear and polar beam patterns (normalized power in $\mathrm{dB}$ ) for case (16) with the radar range margins 


\section{Discussion}

In general, Figures $1-6$ show that, by increasing the number of ULA sensors, the beam pattern lobes are not only thinned but also change in their power (strength). In particular, the interference direction sidelobes become relatively stronger. Therefore, the sensors' number increasing is limited by the three influencing factors: the thinned-array curse transmitted power loss, the aperture size, and the sidelobes intensification.

If the scanning step is wider than the interference direction spacing, then the ULA sidelobe cancellation is not effective, let alone its efficiency. In this case, obviously, the scanning step should be shortened [23], [24], [32], [33]. If the shortening is not possible, a tradeoff between the ULA radar effectiveness and the power-geometry loss must be made [34], [35].

\section{Conclusion}

Based on the simulation results, it is ascertained that an optimal number of ULA radar sensors for the beam pattern synthesis can be found when the scanning step is equal to the least distance between adjacent interference directions. At the start, the number of sensors is set at the number of useful signal directions. Then the multiple direction interference is tried to be suppressed by a canceller routine of (1) - (8). If the mainlobes towards useful signal directions are not evened enough, the set of interference directions is corrected. The correction can be done in two ways. First, directions which are beyond the scanning range can be added into the set for suppressing the interference close to the radar range margins. Second, the interference directions close to the useful signal directions can be slightly "pushed" aside for strengthening those useful signal mainlobes. Along with the abovementioned, the multiple direction interference is indeed efficiently suppressed when the direction spacing in the sets of useful signal and interference directions is the same. Thus, the ULA radar beam pattern synthesis can always be improved by adjusting the radar scanning step as close as possible to the minimal interference direction spacing.

\section{References}

1. R. Sturdivant, C. Quan, and E. Chang, Systems Engineering of Phased Arrays, Norwood, Massachusetts, USA: Artech House, 2018.

2. H. J. Visser, Array and Phased Array Antenna Basics, Hoboken, New Jersey, USA: John Wiley \& Sons, 2006. https://doi.org/10.1002/0470871199
3. T. A. Milligan, Modern Antenna Design, 2nd ed. Hoboken, New Jersey, USA: John Wiley \& Sons, 2005. https://doi.org/10.1002/0471720615

4. W. L. Stutzman and G. A. Thiele, Antenna Theory and Design, 3rd ed. Hoboken, New Jersey, USA: John Wiley \& Sons, 2012.

5. H. Asplund et al., "Chapter 4 - Antenna Arrays and Classical Beamforming," in Advanced Antenna Systems for $5 G$ Network Deployments: Bridging the Gap Between Theory and Practice, P. von Butovitsch, Ed. Cambridge, Massachusetts, USA: Academic Press, 2020, pp. 89 - 132. https://doi.org/10.1016/B978-0-12-820046-9.00004-6

6. N. Fourikis, "Chapter 2 - From Array Theory to Shared Aperture Arrays," in Advanced Array Systems, Applications and RF Technologies: A volume in Signal Processing and its Applications, N. Fourikis, Ed. Cambridge, Massachusetts, USA: Academic Press, 2020, pp. 111 - 217. https://doi.org/10.1016/B978-012262942-6/50004-4

7. M. Skolnik, Introduction to Radar Systems, 3rd ed. New York City, New York, USA: McGraw-Hill, 2001.

8. M. N. Almarshad, M. Barkat, and S. A. Alshebeili, "A Monte Carlo simulation for two novel automatic censoring techniques of radar interfering targets in log-normal clutter," Signal Processing, vol. 88, iss. 3, pp. $719-732,2008$

https://doi.org/10.1016/j.sigpro.2007.09.013

9. W. E. Kock, Radar, Sonar, and Holography: An Introduction, Cambridge, Massachusetts, USA: Academic Press, 1973.

https://doi.org/10.1016/C2013-0-10981-6

10. R. Gui, Z. Zheng, and W.-Q. Wang, "Cognitive FDA radar transmit power allocation for target tracking in spectrally dense scenario," Signal Processing, vol. 183, 108006, 2021.

https://doi.org/10.1016/j.sigpro.2021.108006

11. M.-M. Tamaddondar, H. Keshavarz, and J. Ahmadishokouh, "Beamsteering for non-uniform weighted array-fed reflector antenna," Wireless Personal Communications, vol. 97, pp. 5511 - 5525, 2017. https://doi.org/10.1007/s11277017-4792-0

12. S. J. Orfanidis, Electromagnetic Waves and Antennas, Piscataway, New Jersey, USA: Rutgers University, 2016.

13. M. Gustafsson, C. Sohl, and G. Kristensson, "Physical limitations on antennas of arbitrary shape," Proceedings of The Royal Society A: Mathematical Physical and Engineering Sciences, vol. 463, pp. 2589 - 2607, 2007. https://doi.org/10.1098/rspa.2007.1893

14. V. V. Romanuke, "Computational method of building orthogonal binary functions bases for multichannel communication systems with code channels division," Mathematical Modeling and Computational Methods, Ternopil, Ukraine: Ternopil State Technical University, 2006. 15. W.-Q. Wang and H. Shao, "Radar-to-radar interference suppression for distributed radar sensor networks," Remote Sensing, vol. 6, iss. 1, pp. 740-755, 2014. https://doi.org/10.3390/rs6010740

16. K. N. Le, "A review of selection combining receivers over correlated Rician fading," Digital Signal Processing, 
vol. 88, pp. $1-22,2019$.

https://doi.org/10.1016/j.dsp.2019.01.015

17. A. A. Mulla and P. N. Vasambekar, "Overview on the development and applications of antenna control systems," Annual Reviews in Control, vol. 41, pp. $47-57,2016$.

https://doi.org/10.1016/j.arcontrol.2016.04.012

18. A. Oxley, "Chapter $4-$ Signals From Satellites to Receiver - GPS," in Uncertainties in GPS Positioning, A. Oxley, Ed. Cambridge, Massachusetts, USA: Academic Press, pp. $61-70,2017$

https://doi.org/10.1016/B978-0-12-809594-2.00004-6

19. A. Oxley, "Chapter 11 - Improving Accuracy With GPS Augmentation," in Uncertainties in GPS Positioning, A. Oxley, Ed. Cambridge, Massachusetts, USA: Academic Press, pp. 129 - 134, 2017. https://doi.org/10.1016/B978-0-12-809594-2.00011-3

20. A. Sleiman and A. Manikas, "The impact of sensor positioning on the array manifold," IEEE Transactions on Antennas and Propagation, vol. 51, no. 9, pp. 2227 - 2237, 2003.

https://doi.org/10.1109/TAP.2003.816333

21. G. Efstathopoulos, G. Elissaios and A. Manikas, "The effect of uncertainties on the performance of array systems," in 2007 IEEE 18th International Symposium on Personal, Indoor and Mobile Radio Communications, Athens, Greece, 2007, pp. $1-5$.

https://doi.org/10.1109/PIMRC.2007.4394039

22. E. Dahlman, S. Parkvall, and J. Sköld, "Power Control, Scheduling, and Interference Handling," in 4G: LTE/LTE-Advanced for Mobile Broadband, E. Dahlman, S. Parkvall, J. Sköld, Eds. Cambridge, Massachusetts, USA: Academic Press, 2011, pp. $265-299$.

https://doi.org/10.1016/C2013-0-06829-6

23. L. Borowska, G. Zhang and D. S. Zrnic, "Spectral processing for step scanning phased-array radars," IEEE Transactions on Geoscience and Remote Sensing, vol. 54, no. 8, pp. $4534-4543,2016$.

https://doi.org/10.1109/TGRS.2016.2543724

24. P. Fritsche and B. Wagner, "Evaluation of a novel radar based scanning method," Journal of Sensors, vol. 2016, Article ID 6952075, 2016.

https://doi.org/10.1155/2016/6952075

25. V. V. Romanuke, "Equidistant phase commutation by an algorithm based on a system of noncyclic binary elements using four of eight active phases," Herald of Technological University of Podillya. Technical sciences, no. 5, pp. 169 174, 2004.
26. S. Alland, W. Stark, M. Ali, and M. Hegde, "Interference in automotive radar systems: characteristics, mitigation techniques, and current and future research," IEEE Signal Processing Magazine, vol. 36, no. 5, pp. 45 - 59, 2019.

https://doi.org/10.1109/MSP.2019.2908214

27. G. Hakobyan, K. Armanious, and B. Yang, "Interference-aware cognitive radar: a remedy to the automotive interference problem," IEEE Transactions on Aerospace and Electronic Systems, vol. 56, no. 3, pp. $2326-2339,2020$.

https://doi.org/10.1109/TAES.2019.2947973

28. V. V. Romanuke, "Interval uncertainty reduction via division-by-2 dichotomization based on expert estimations for short-termed observations," Journal of Uncertain Systems, vol. 12, no. 1, pp. 3-21, 2018.

29. V. V. Romanuke, "A minimax approach to mapping partial interval uncertainties into point estimates," Journal of Mathematics and Applications, vol. 42, pp. 147 - 185, 2019. https://doi.org/10.7862/rf.2019.10

30. W. Huang and R. Lin, "Efficient design of doppler sensitive long discrete-phase periodic sequence sets for automotive radars," in 2020 IEEE 11th Sensor Array and Multichannel Signal Processing Workshop (SAM), Hangzhou, China, 2020, pp. $1-5$.

https://doi.org/10.1109/SAM48682.2020.9104358

31. C. Aydogdu et al., "Radar interference mitigation for automated driving: exploring proactive strategies," IEEE Signal Processing Magazine, vol. 37, no. 4, pp. $72-84$, 2020

https://doi.org/10.1109/MSP.2020.2969319

32. S. Torres and D. Warde, "Ground clutter mitigation for weather radars using the autocorrelation spectral density," Journal of Atmospheric and Oceanic Technology, vol. 31, no. 10, pp. $2049-2066,2014$.

https://doi.org/10.1175/JTECH-D-13-00117.1

33. R. J. Doviak and D. S. Zrnić, "Chapter 3 - Radar and Its Environment," in Doppler Radar and Weather Observations, 2nd ed. R. J. Doviak and D. S. Zrnić, Eds. Cambridge, Massachusetts, USA: Academic Press, 1993, pp. $30-63$.

https://doi.org/10.1016/B978-0-12-221422-6.50008-5

34. F. Vincent, O. Besson, S. Abakar-Issakha, Laurent Ferro-Famil, and F. Bodereau, "On the tradeoff between resolution and ambiguities for non-uniform linear arrays," in 2016 IEEE Global Conference on Signal and Information Processing (GlobalSIP), Washington, USA, 2016, pp. $1052-1055$.

35. M. H. Er, "Array pattern synthesis with a controlled mean-square sidelobe level," IEEE Transactions on Signal Processing, vol. 40, no. 4, pp. 977-981, 1992. https://doi.org/10.1109/78.127971

\section{Романюк В. В.}

Заглушення інтерференції за множинними напрямками ефективним нейтралізатором бічних пелюсток рівномірно-лінійної фазованої антенної решітки

Проблематика. Діаграма спрямованості рівномірно-лінійної фазованої антенної решітки (РЛФАР) в радіолокаційних системах синтезується для забезпечення вибірковості за напрямком. Визначена бокова пелюстка 
РЛФАР пригнічується за допомогою підгонки вагових коефіцієнтів. Зокрема, це здійснюється збільшенням кількості сенсорів і скороченням кроку сканування. Однак одним з істотних обмежень $є$ втрата потужності. Тому проблема полягає в оптимальному балансуванні кількості сенсорів задля ефективного пригнічення бічних пелюсток РЛФАР.

Мета дослідження. Для заглушення інтерференції за множинними напрямками необхідно знайти оптимальну кількість сенсорів радарів на основі РЛФАР для синтезу діаграми спрямованості. Критерієм є визначенням мінімуму таких сенсорів, за якого головні пелюстки за напрямками корисного сигналу вирівняні якомога краще.

Методика реалізації. Для досягнення мети проводиться симуляція пригнічення бічних пелюсток РЛФАР. Симуляція та іiі конфігурування відбуваються за допомогою функцій MATLAB ${ }^{\circledR}$ R2020b Phased Array System Toolbox $^{\mathrm{TM}}$ на основі алгоритму нейтралізації бічних пелюсток.

Результати дослідження. Зі збільшенням кількості сенсорів РЛФАР пелюстки діаграми спрямованості не лише загострюються, але також і змінюються за потужністю. Зокрема, бічні пелюстки за напрямками інтерференції посилюються. Кількість сенсорів обмежено за трьома факторами впливу: збитковість втрати потужності загострених пелюсток РЛФАР, розмір апертури, посилення бічних пелюсток.

Висновки. Оптимальна кількість сенсорів радарів на основі РЛФАР для синтезу діаграм спрямованості може бути знайдена тоді, коли крок сканування рівний мінімальній відстані між суміжними напрямками інтерференції. Спочатку кількість сенсорів дорівнює кількості напрямків корисного сигналу. Якщо головні пелюстки за напрямками корисного сигналу вирівняні недостатньо, множина напрямків інтерференції корегується.

Ключові слова: фазована антенна решітка радара; діаграма спрямованості; напрямок інтерференції; пригнічення бічних пелюсток; розмір апертури.

\section{Романюк В. В.}

Подавление интерференции по множественным направлениям эффективным подавителем боковых лепестков равномерно-линейной фазированной антенной решётки

Проблематика. Диаграмма направленности равномерно-линейной фазированной антенной решётки (РЛФАР) в радиолокационных системах синтезируется для обеспечения избирательности по направлению. Определённый боковой лепесток РЛФАР подавляется при помощи подгонки весовых коэффициентов. В частности, это осуществляется увеличением количества сенсоров и сокращением шага сканирования. Однако одним из существенных ограничений является потеря мощности. Поэтому проблема состоит в оптимальном балансировании количества сенсоров в отношении эффективного подавления боковых лепестков РЛФАР.

Цель исследования. Для подавления интерференции по множественным направлениям необходимо найти оптимальное количество сенсоров радаров на основе РЛФАР для синтеза диаграммы направленности. Критерием является определение минимума таких сенсоров, при котором главные лепестки по направлениям полезного сигнала выровнены как можно лучше.

Методика реализации. Для достижения цели проводится симуляция подавления боковых лепестков РЛФАР. Симуляцию и её конфигурирование производят при помощи функций MATLAB® R2020b Phased Array System Toolbox $^{\mathrm{TM}}$ на основании алгоритма подавления боковых лепестков.

Результаты исследования. С увеличением количества сенсоров РЛФАР лепестки диаграммы направленности не только заостряются, но также и изменяются по мощности. В частности, боковые лепестки в направлениях интерференции становятся сильнее. Количество сенсоров ограничено по трём влияющим факторам: ущербность потери мощности заострённых лепестков РЛФАР, размер апертуры, усиление боковых лепестков.

Выводы. Оптимальное количество сенсоров радаров на основе РЛФАР для синтеза диаграмм направленности может быть найдено тогда, когда шаг сканирования равен минимальному расстоянию между смежными направлениями интерференции. Вначале количество сенсоров равно количеству направлений полезного сигнала. Если главные лепестки по направлениям полезного сигнала выровнены недостаточно, множество направлений интерференции корректируется.

Ключевые слова: фазированная антенная решётка радара; диаграмма направленности; направление интерференции; подавление боковых лепестков; размер апертуры. 